\title{
THE FUNCTION OF SHARIA SUPERVISORY BOARD IN FINANCING PRACTICES BY SHARIA BANK IN INDONESIA
}

\author{
Prawitra THALIB ${ }^{1}$ \\ Hilda Yunita SABRIE ${ }^{2}$ \\ Faizal KURNIAWAN ${ }^{3}$
}

\author{
Received Date (Başvuru Tarihi): 21/10/2018 \\ Accepted Date (Kabul Tarihi): 02/11/2018 \\ Published Date (Yayın Tarihi): 04/01/2019
}

\begin{abstract}
This research aims to describe the effectiveness of supervisory functions in Islamic banking and finance in Indonesia. To this end, this work uses descriptive quantitative research applying Library Approach. As an intermediary institution based on sharia principles, sharia banks must perform two compliances, namely sharia principle and law compliance. The application of these compliances is not only required for good corporate governance and diverse products of sharia bank, but also for financial deeds made by a notary. Therefore, financial deeds in sharia banks must reflect the sharia compliance principle instead of only reflecting the law compliance. Special concern about sharia compliance has become authority scope from the Sharia Supervisory Board. Thus, Sharia Supervisory Board does not only ensure the application of sharia compliance but also every deed based on Islamic principles built by a notary. Failure to fulfill the sharia principles in a sharia bank financing deed can cause such deed to be null and void.
\end{abstract}

Keywords: Sharia Bank, Sharia Supervisory Board, Sharia Compliance, Finance Deed, Sharia Principle JEL Codes: E58, F36, G41

\section{ŞERİAT DENETLEME KURULUNUN ŞERIAT BANKALARI TARAFINDAN GERÇEKLEŞTİRILEN FINANSAL AKTIVITILERIN ÜZERINDEKİ FONKSIYYNU}

ÖZ

Bu çalışmanın amacı, Endonezya'daki İslami bankacılı̆̆ın ve finans aktivitelerinin üzerinde, denetleme kurulu fonksiyonlarının etkiliğini açıklamaktır. Bu bağlamda çalışmada, Kütüphane Yaklaşımı uygulanarak açıklayıcı niceliksel araştırma yapılmışıtı. Şeriat prensiplerine dayanan ve aracı bir kurum olan şeriat bankalarının şeriat hükümlerine ve yasal hükümlere olmak üzere iki tür uyum göstermesi gerekmektedir. Bu hükümlerle uyumlu olan uygulamalar, yalnızca kurumsal yönetim için değil, noter tarafindan gerçekleştirilen finansal aktiviteler için de gerekli olmaktadır. Bu yüzden, şeriat bankalarındaki finansal aktiviteler yalnizca hukuki hükümleri değil şeriat hükümlerini de yansıtmak zorunda olmaktadır. Şeriat uygulamaları, Şeriat Denetim Kurulu için otorite kapsamında değerlendirilmektedir. Bundan dolayı Şeriat Denetim Kurulu sadece șeriat hükümlerine uyumu değil noter tarafindan gerçekleştirilen tüm aktivitelerin de İslami hükümlere dayalı olmasını sağlamaktadır. Şeriat bankacıllğındaki finansal aktivitelerinde bu dayanağın eksik olmast ise, bu aktivitelerin geçersiz olmasina sebebiyet verebilmektedir.

Anahtar Kelimeler: Sharia Bank, Sharia Supervisory Board, Sharia Compliance, Finance Deed, Sharia Principle JEL Kodlart: E58, F36, G41

\footnotetext{
${ }^{1}$ Faculty of Law, Airlangga University, Surabaya, Indonesia, prawitrathalib7@gmail.com

${ }^{2}$ Faculty of Law, Airlangga University, Surabaya, Indonesia, hildasabrie7@gmail.com

${ }^{3}$ Faculty of Law, Airlangga University, Surabaya, Indonesia, faizalfhunair@gmail.com
}

https://orcid.org/0000-0003-1025-9967 https://orcid.org/0000-0002-6262-7314 https://orcid.org/0000-0002-0855-3369 


\section{INTRODUCTION}

Sharia bank is becoming a well-known bank in Indonesia, where people are mostly Muslims. Sharia bank is one of the economic systems of sharia, a part of Islamic teaching that regulates the economic area. This is embedded in the aspects of comprehensive and universal Islamic teachings. While comprehensive means that Islamic teaching comprehends all aspects of life (social, ritual ...) universal suggests that Islam can be applied every time and everywhere regardless of race, ethnicity, social class or other distinctive factors. This idea is encapsulated in the Islamic principle "rahmatan lil alamin" (mercy to the worlds). The four main principles that underlie the banking network within the system of sharia are:

1. Non-usury banking

2. Legal business

3. Satisfaction of the contracting parties, and

4. Honest and responsible management of funds.

Based on the development of sharia bank and the society's requirement, the financial services authority (OJK) needs to expend efforts to enable a consistent growth and improvement of sharia bank. OJK's efforts to complete the provisions based on the characteristics of financial services authority regulations (POJK) as the implementing banking law, so it can improve the society's understanding of sharia bank.

To align the existence of sharia banks, OJK and Bank Indonesia cooperate with the Indonesian Ulema Council (MUI). The latter is an institution that supervises the implementation of sharia principles in Indonesia. This cooperation has established the National Sharia Board (DSN) and Sharia Supervisory Board (DPS). DPS is an organ of sharia bank management based in its head-office and in line with the Board of Commissioners. The members of the DPS arenominated during the General Meeting of Shareholders (GMS). The effectiveness of the supervisory functions in the application of Islamic banking and finance in Indonesia remains questionable. Therefore, this research will focus on the supervisory functions exerted by the institutions to whom the task has been appointed.

\section{LITERATURE REVIEW}

The National Sharia Council (DSN) was established in early 1999. This institution aims to reviewand formulate the values and principles of Islamic law and oversee the institutionalized transactions and other activities in sharia finance.

In addition to the contriving of an effective sharia banking system, a Sharia Supervisory Council (DPS) is established to superintend the business and operational activities with a fatwa 
issued by the DSN. The DPS is in charge of aligning the products and services offered to customers, investments and projects conducted by the bank to the sharia principles and also has to present to the DSN development plan of the bank's products and services.

The Sharia Supervisory Board is an independent institute installed by the National Supervisory Council (DSN) in Islamic banks and other financial institutions. Membership of DPS requires an expertise in sharia muamalah combined with knowledge in the field of banking economy. The main assignment of the DPS is to supervise and maintain the conformity of the bank's business activities with the principles determined by DSN.

\section{RESEARCH METHOD}

This research uses descriptive and quantitative research methods. Descriptive method utilizes the analysis of the factors related to the problem intended as a supporting data. The technique of data collection is Study Library, which refers to researches conducted by collecting data or materials from a number of literature.

\section{DISCUSSION}

Based on the article 35 paragraph (1) of PBI No 11/3 / PBI / 2009, in general, the functions of the DPS are providing advice to the Board of Directors and maintaining the bank activities in accordance with the sharia principles. The paragraph (2) states that the implementation of responsibilities of the DPS as mentioned in paragraph (1) includes:

1. Assess and ensure compliance with Sharia Principles on operational guidelines and products issued by banks;

2. Supervise the process of developing new products of banks;

3. Requesting fatwa from the National Sharia Council (DSN) about new products that have no fatwa yet;

4. Conduct the review of Sharia Principle fulfillment on fund raising mechanism and channeling of funds and bank services; and

5. Request informational data related to sharia aspect from bank in their duties.

The Decree of the National Sharia Council of the Indonesian Council of Ulama No. 2/2000 on the Guidelines of the Household of the National Sharia Council of the Indonesian Council of Ulama, stipulates that the DPS in each financial institution has the following main duties:

1. Providing advice to directors, head of sharia business unit and head of sharia financial institution branch on matters with a sharia aspect; 
2. Supervising, either actively or passively, the implementation of the National Sharia Council, and directing products and business activities in accordance with the principles of sharia;

3. As a mediator between sharia financial institutions and the National Sharia Council, communicating and suggesting a development of products of Islamic financial institutions that require the study and the fatwa of the National Sharia Council.

In the theory of corporate law, the doctrine of fiduciary duty is the theory, which emphasizes that a person case of performing his duty acts on behalf of the other is based on a trust relationship. The trust relationship entails a trustee and an agent. Based on this, one can concludethat the the responsibility of a DPS in a sharia bank outline consists of two main tasks, namely:

1. Liabilities in the management of a sharia bank (a trustee) by supervising the implementation of sharia principles; and

2. Obligation to perform the functions of representatives of sharia banks (an agent) in the communication of the National Sharia Council of the Indonesian Council of Ulama (DSNMUI) and reporting to Bank Indonesia regarding the supervision of the implementation of sharia compliance of an Islamic bank (Harris \& Anggoro, 2010:50).

To enforce supervision so that the implementation of banking be in accordance with the principles of sharia and prevailing laws and regulations, the DSN-MUI establishes a DPS in every Islamic financial institution. Thus, the task of the DPS is to carry out the supervisory function of the existing sharia aspects in the banking system; although technically, the supervision of sharia banking remains the authority of the OJK.

This latter issued Regulation of Financial Services Authority No 30 / POJK.05 / 2014 on Good Corporate Governance for Financing Companies. The regulation assigns the DPS in Chapter VII of Article 32 - Article 42. In the case of POJK financing arranged in Article 38, the following:

1. DPS shall perform the duties of supervising and advising the Board of Directors for the activities of Sharia (Islamic) Financing Companies in accordance with Sharia principles;

2. Implementation of the duties of supervising and giving advice by DPS as referred to in paragraph (1) shall be conducted on:

a. Sharia financing activities;

b. Sharia financing contracts;

c. Sharia Financing Marketing Practices 
3. In performing the duties of supervision and giving advice as referred to in Paragraph (2), the DPS may be assisted by committee members whose organizational structure is under the Board of Commissioners.

\subsection{Sharia Compliance}

According to Syarifin, the legal consequence is all the consequences that result from all legal acts committed by the subject the law against the object of law or other consequences caused by certain events by the law concerned has been determined or deemed as a result of law. The consequences of the law itself can be tangible:

1. The incipience, change, or discontinuance of a state of law. For example: an initially legally incompetent young person obtains legal competence by reaching adulthood.

2. The incipience, change, or discontinuance of a legal relationship, between two or more legal subjects, in which the rights and duties of one party deal with the rights and obligations of the other. Example: purchase agreement;

3. The commencement of sanctions if the act is unlawful;

4. Legal consequences arising from the existence of emergency events by the law concerned are regarded as legal effects.

The provisions in Law No 2 of 2014 concerning Amendment to Law No 30 Year 2004, regard Notary Position (UUJN) and the provisions in law No. 21/2008, can be canceled (vernietigbaar) or considered null and void (nietig), a deed of treaty which does not meet the agreement's legal requirements. An agreement that does not meet the objective requirements, that is certain objects and prohibited power, then the agreement is null and void. Nullifying by law means that the legal act is considered as never existed and is not a legitimate legal product.

An agreement which does not meet the subjective requirements can be canceled only by filling a cancellation request with prove to the court, otherwise the agreement still applies to the parties. After the examination of the agreement or the notary deed, the judge either cancels or declares them null and void. The consequences resulting from a violation of the agreed terms depend on the nature of the violation: either it pertains to subjective or objective requirements. While the former causes the cancellation, the latter causes the agreement to be considered null and void.

Regarding the deed or sharia bank account, the format of the document is not regulated in Law no. 21/2008, the format of the sharia banner agreement is generally uniform and almost the same as the general agreement format, as it is subject to the terms and according to the customs prevailing among Indonesian legal practitioners. Thus, the validity of the sharia bank acts besides the conformance with Article 38 UUJN, requires the bank to respect the principles 
of Islamic law. This suggests that the bank's undertakings should not include any element gharar (deceptive), maysir (gambling), riba (interest), zulm (unjust), rishwah (bribery) or haram (prohibited) products and services.

The activities of a sharia bank should be based on the legal rules relating to the procedure of notarial deed and sharia principles. The notary making the Islamic bank deed is required to have a profound comprehension of the contents of sharia bank contract with its customers. In addition to respecting the existing legal principle (law compliance), a notary must also observe sharia principles (sharia compliance) while making a deed. A contract is depicted not violating the principles of sharia if it does not violate the provisions of Article 2 of Law No. $21 / 2008$, pertaining to sharia banking's business activities based on Islamic law, economic democracy, and prudential principles.

Article 1 Sub-Article 13 of Law. 21/2008 states that "a contract is a written agreement between a sharia bank or UUS and any other party which contains rights and obligations for each party in accordance with sharia principles". A contract that does not meet or contains elements non-conform with sharia principles is considered null and void, based on Article 28.3 of the Compilation of Islamic Economic Law (KHES) stating that "a canceled contract is a less harmonious contract and / or conditions". In other words, the deed or contract made by notary which is not in accordance with ruling legal principles or violates the principles of sharia, is null and void.

A customer who engages in fund misuse by conducting prohibited business activities, though the contract is legal and meets the terms and sharia requirements, is said to have contravened the agreement. A breach or default of promise is a case in which a customer does not respect the agreement's requirements and act accordingly.

The Article 36 of KHES mentions that a party is regarded as breaking the agreement by:

1. Failing to do what is promised;

2. Conducting in a different way from what is promised;

4. Not respecting the deadlines; or

5. Engaging in an activity prohibited by the agreement.

The party in a contract failing to meet the promise may be subject to sanctions ranging from the cancellation of the contract, the transfer of risk to paying compensation, fine or court fee. Indemnity payment sanctions are imposed if:

1. A party continuously breaks the agreement;

2. Anything that must be given or made, has exceeded the deadline; 
3. A party who breaks a promise cannot prove that the disobedient acts committed are not. Thus, the legal protection in Islamic banks can be divided into two aspects; namely the protection of internal law and the protection of external law. The former refers to the implementation by the bank of sharia principles (sharia compliance). This is done by means of DPS and sharia bank compliance organs must verify every deed made by a notary before being signed by the bank and the customer. The latter (the protection of external law) has not set specific norms. However, through OJK legal protection can be done by granting the supervisory board the authority to impose sanctions upon a notary who makes a deed which is not in accordance with the principles of sharia (sharia compliance). So far, the existing legal protection has been only in the forefront for customers, but not for sharia banks (such as regulated in laws and POJK regulating consumer protection). Thus, a balanced protection of the law between the bank and its customers is needed in order to develop trustful interactions.

\subsection{Sanctions Upon Notary Resulting From Disobedience of Sharia Principles}

Sanctions represent an essential part of the law and each law, that prevails in Indonesia, constitutes a sanction. Inclusion of sanctions in the various rules of law is an obligation that must be included in each rule of law, and anyone who violates the rule of law will be sentenced to criminal, civil, and administrative sanctions. Thus, law offenders can be subject to cumulative sanctions. The relevant legal rules cannot be enforced or will not be obeyed unless at the end they include sanctions. Enforcing a rule of law which cannot be imposed and supported by sanctions is pointless.

Sanctions against notaries are provided in Article 84 and Article 85 UUJN, namely:

\subsubsection{Civil Sanction}

Sanctions in the form of expenses reimbursement, compensation and interest, are imposed when the agreement is judged null and void.

Notary deeds that have perfect proof power, for violating certain provisions, will undermine the value of proofing to have a proof power as a deed under the hand. The notary position of the notary deed which then has the evidentiary power as a deed under the hand, constitutes an appraisal of an evidence. While a deed is null and void, then the deed is considered never existed or never made. Something that is never made cannot be the basis of a claim in the form of reimbursement of costs, compensation, and interest. Therefore, a notary deed that is null and void shall have no effect to provide reimbursement of fees, compensation and interest to the parties in the deed. Reimbursement of costs, damages and interest may be 
required to the notary must be based on a legal relationship between a notary and the parties to the notary. If there is party feels harmed directly from a notary deed, hence the concerned can demand the civil litigation to the notary.

Article 84 of the UUJN is stipulated that there are 2 (two) types of civil sanctions, if the notary commits a violation of certain articles, namely:

a. Notary deeds have evidentiary power as deeds under the hand; and

b. The notary deed becomes null and void.

\subsubsection{Administrative Sanction}

In Article 85 UUJN mentioned 5 (five) types of sanctions, namely:

a. Verbal reprimands;

b. Written reprimands;

c. Dismissal with respect;

d. Dismissal is not honorable.

According to Berge, Law enforcement includes supervision and enforcement of sanctions. Supervision is a preventive and repressive effort to enforce compliance. In the application of administrative sanctions against notaries, who are the watchdog instruments of the Supervisory Council that takes preventive measures to impose compliance, to apply repressive sanctions and to impose compliance in order for sanctions, such sanctions can be implemented. Preventive measures shall be undertaken with a yearly inspection(or at any time deemed necessary) to ensure that notaries exercise their functions according to the Regional Supervisory Board (MPD). Then this latter has to report any suspected criminal element to the National Supervisory Board (MPW). The notary has then to account for the alleged violation of a notary code of ethics or a violation of the execution of a notary. MPW can carry out repressive efforts by imposing sanction in the form of written or oral warning and final sanction (Article 73 paragraph (1) letter e and paragraph (2) UUJN), and propose sanction against notary by Central Supervisory Board (MPP) in the form of:

a. Temporary dismissal for 3 (three) months up to 6 (six) months; or

b. Dismissal with dishonor

Sanctions in Articles 85 and 86 of the UUJN comprehend oral reprimands, dishonorable dismissals and internal sanctions. This latter refers to sanctions against a notary for disregarding a series of ordered duty conducts, set for the notary's benefit, in carrying out his duties. 


\subsubsection{Criminal Sanctions}

A notary partial incrimination occurs when:

a. A deed made by or in the presence of a notary serves as a basis for committing a crime;

b. A tested legal action of a notary in making a deed or a deed made in his presence does not observe the UUJN requirements;

Such a notary act is not appropriate, according to the authorized institution (in this case the Notary Public Notary) to assess the act of a notary.

The imposition of criminal sanctions on a notary can be made as long as the above limits are transgressed. Thus, a notary, besides fulfilling the formulation of the violation in the UUJN and the Notary Code of Ethics, also has to fulfill the elements mentioned in Article 322 paragraph (1) and (2) of the Criminal Code referring to the disclosure of secrets he is obliged to keep. Criminal sanctions are ultimum remidium, the last weapon, after all the attempts or sanctions implied in other branches of the law are considered ineffective or incapable of correcting a criminal action. Therefore, its use should be limited. In other words criminal sanctions should be applied uniquely in case all other kinds are inadequate.

\section{CONCLUSION}

The Legis Ratio need for the DPS supervision of notary deeds in sharia banks is meant to ensure the implementation of the banking principles of sharia in Indonesia. The implementation of sharia principles in kaffah (total Islam) plays a key role in maintaining the reputation and enhancing the public confidence in Islamic financial institutions. However, in practice such efforts should also be in accordance with the application of sharia principles in kaffah (total Islam) by the notary who makes the deeds of Islamic banks. The Article 32 No 3 of Law No. 21/2008 grants the DPS the authority to guarantee the respect of Sharia Compliance in the practices of sharia banks. In order to ensure a thorough application of Sharia Compliance, the DPS also oversees the substance of notary deeds related to Islamic banks.

Therefore, the deeds which fail to conform to the principles of sharia are consequently null and void. Expressly, it is said to be discordant and imperfect (implies nullity and voidness) an agreement whose terms are incompatible with the Islamic law requirements. Thus, the importance of observing the tenets of sharia in order to preserve the terms and maintain a harmonious contract is rather clear. Therefore, a synergy between the notary act as the certificate maker and the DPS is required to conduct the verification of the deed. 


\section{REFERENCES}

Developing team of Syaria Bank. 2007. Institut Bankir Indonesia, Djambatan, Jakarta, 2007.

Finance authority regulations No 1/POJK.07/2013 about consumer protection of sector finance.

Finance authority regulations No 30/POJK.05/2014 about corporate finance company

Finance authority regulation No 31/POJK.05/2014 about Business of Syaria Finance.

Harris, F and Anggoro, T. 2010. Hukum Perseroan Terbatas: Kewajiban Pemberitahuan oleh Direksi. Jakarta: Ghalia Indonesia.

Hadjon, M. P. 2002. Pengantar Hukum Administrasi Indonesia, Yogyakarta: Gadjah Mada University Press.

Indonesia Bank No 11/3/PBI/2009 about Syariah Bank.

Indonesia Bank No 13/23/PBI/2011 about Risk Management for Syaria Bank and Unit of Syaria Business.

Ishaq. 2009. Dasar-Dasar Ilmu Hukum, Jakarta: Sinar Grafika.

Kartikasari, N. 2010. Pertanggungjawaban Notaris Dalam Pembuatan Akta dan Akibat Hukumnya, Thesis, Magister of Notary, Law Faculty, Airlangga University, Surabaya.

Khalil, J. 2002. "Prinsip Syariah dalam Perbankan”, Business law journal.20.

Laws No 21 of 2008 Syaria Bank, Paper of Indonesia Republic 2008 No. 94

Laws No 2 of 2014 about Amandment of laws No 30 of 2004 about Notary Office, Paper of

Indonesia Republic 2014 No 3.

Pratiwipuspa, L. 2010. Keabsahan Akta Akad Bank Syariah Yang Dibuat Oleh Notaris

Yang Tidak Bersertifikat Lembaga Keuangan Syariah, Thesis, Magister of notary, law faculty, Airlangga University, Surabaya.

Sudarsono, H. 2003. Bank dan Lembaga Keuangan Syariah Deskripsi dan Ilustrasi, Jogjakarta: Ekonisia.

Sudarto. 1987. Hukum Pidana I, Badan Penyedia Bahan-Bahan Kuliah Fakultas Hukum Diponegoro University, Semarang, pp.13.

Supreme Court Regulations No 2 of 2008 about Law Compilation of Syaria Economic.

Sutedi, A. 2009. Perbankan Syariah, Ghalia Indonesia, Bogor.

Syarifin, P. 2009. Pengantar Ilmu Hukum, Bandung: Pustaka Setia.

Wicaksono, A. D. 2003. Pengawasan Kegiatan Usaha Pada Bank Syariah, Thesis, Law Faculty of Airlangga University.

Wienantya, A. S. 2009. Sanksi Terhadap Notaris Atas Pelanggaran Kewajiban Terkait Dengan Pembuatan Akta, Thesis, Magister of notary Law faculty, Airlangga University, Surabaya. 